International Journal of Agriculture, Environment and Bioresearch

Vol. 4, No. 04; 2019

ISSN: $2456-8643$

\title{
DETERMINATION OF PESTICIDE RESIDUES IN ORGANIC AND CONVENTIONAL EXOTIC VEGETABLES
}

\author{
Kenyanya Teresa Mogoi ${ }^{1}$, Wilkister Nyaora Moturi ${ }^{1}$, Jane Nyaanga ${ }^{2}$, Joseph Kinyoro Macharia ${ }^{2}$ and Rhoda \\ Jerop Birech ${ }^{2}$ \\ ${ }^{1}$ Department of Environmental Science, Egerton University, \\ ${ }^{2}$ Department of Crops, Horticulture and Soils, Egerton University \\ http://doi.org/10.35410/IJAEB.2019.4402
}

\begin{abstract}
Pesticides are used to protect crops from diseases and pests. They have been used in growing vegetables especially exotic vegetables that are more prone to pests and diseases. There have been concerns over indiscriminate use of pesticides by farmers to grow vegetables especially for local markets since there are no guidelines on Maximum residue levels. This study was done to determine the concentration of cypermethrin and lambda-cyhalothrin pesticide residues in Collard (Brassica oleracea var. acephala) Tomatoes (Solanum lycopersicum) and swiss chard (Beta vulgaris subsp. cicla). The samples included both organic and conventional vegetables that use chemical pesticides. Experimental study design was used which involved laboratory analysis of the samples. Sample extraction was done using AOAC official method 2007.01 known as Quick, Easy, Cheap, Effective, Rugged and Safe (QuEChERS) method. The method involves use of Acetonitrile, sodium chloride and anhydrous magnesium sulphate for extraction. Clean-up was done using dispersive-solid phase extraction method using Primary-Secondary Amine and anhydrous magnesium sulphate. Residues analysis was done using Reverse-phase High Performance Liquid chromatography. Peak areas of the curves were calculated using Motic Images plus 2.0 and data analysis was done using SPSS 22. The results indicated that organic vegetable samples had pesticide residues below detectable levels while conventional vegetable samples had levels ranging from $2.495 \mathrm{mg} / \mathrm{kg}$ to $0.238 \mathrm{mg} / \mathrm{kg}$ for cypermethrin and $0.352 \mathrm{mg} / \mathrm{kg}$ to $0.119 \mathrm{mg} / \mathrm{kg}$ for lambda-cyhalothrin.
\end{abstract}

Keywords: Pesticide residues, Vegetables, Cypermethrin, Lambda-cyhalothrin.

\section{INTRODUCTION}

Pests and plant diseases have been a problem to vegetable farmers and a threat to food security globally as they destroy crops and reduce yields hence financial losses. Pests are organisms that feed on plants as a source of food (Ata et al., 2013). Pests can be carriers of plant pathogens which also exist in soil. Farmers use pesticides to control the pests and plant diseases. Pesticides have been in use since early years by Sumerians where they used compounds of sulphur, mercury, lead, zinc and arsenical compounds to grow vegetables and fruits (Unsworth, 2010). Before the invention of chemical industries, most pesticides were derivatives of plants and animals (Fishel, 2013). 
Chemical pesticides are widely used globally as they are perceived to be more effective and relatively cheap. Kenya being a country that widely relies on agriculture, there is widespread use of chemical pesticides to control plant diseases and pests. This is in effort to improve yield and produce blemish-free products. Emergence of new diseases and pests has led to the need of better pesticides to counter this problem. Farmers are encouraged to embrace new methods of controlling plant diseases and pests such as integrated pest management to reduce reliance on chemical pesticides. Despite this effort, use of chemical pesticides is still wide spread in the country.

Most chemical pesticides cause negative health effects to human beings especially if exposed to high doses. They can affect the respiratory system, nervous system and interfere with the function of cell membrane of target and non-target organisms (Corbett, 1974). For this reason, it is important to prevent excessive exposure of humans to pesticides. Occupational exposure to these pesticides can be controlled by educating the handlers on use of protective equipment during usage. Dietary exposure to pesticides through residues can also be controlled by ensuring that farmers adhere to good agricultural practices, practicing organic agriculture and complying with the recommended maximum residue levels (MRLs).

The objective for this study was to determine the concentration of pesticide residues in locally consumed vegetables. The hypothesis was that pesticide residues in locally consumed vegetables were above the recommended Maximum residue Levels.

\section{MATERIALS AND METHODS}

\subsection{Study Areas}

Nakuru town and parts of Nairobi were the study areas included in the study. Three open air markets in Nakuru town were selected, they included, Soko-mjinga, Ponda-mali and Main Municipal Markets for conventional vegetables. Kalimoni Greens, Carre four supermarket and Karen Organic Market located in Nairobi for organic vegetables also included in the study. The two study areas were chosen since they had similarities in pesticide use.

\subsection{Sampling of vegetables for analysis}

The vegetables included in the study were Collard greens (Brassica oleracea var. acephala), Tomatoes (Solanum lycopersicum) and Swiss chard (Beta vulgaris subsp. cicla). The samples included both conventional and organically grown vegetables. The vegetables were randomly sampled and were bought in triplicates. They were packaged in polythene bags, labelled and stored at temperatures below $5^{\circ} \mathrm{C}$ for transportation to the laboratory.

\subsection{Extraction of Pesticide residues from vegetables}

Quick, Easy, Cheap, Effective, Rugged and Safe Method also known as the QuEChERS was used in the analysis of pesticide residues (Anastassiades et al., 2003). This method is also registered as AOAC 2007.01 official method for pesticide residue analysis. Triplicates of vegetable samples were chopped and shredded in a blender to obtain a homogeneous composite sample. $10 \mathrm{~g}$ of the homogenized sample was weighed into $50 \mathrm{~mL}$ Teflon centrifuge tube. $10 \mathrm{~mL}$ 
of $\mathrm{MeCN}$ was added using a dispenser (pipet), and the sample was vigorously shaken for $1 \mathrm{~min}$ using a Vortex mixer at maximum speed. $4 \mathrm{~g}$ anhydrous $\mathrm{MgSO}_{4}$ and $2 \mathrm{~g} \mathrm{NaCl}$ was added and mixed immediately on a Vortex mixer for $1 \mathrm{~min}$. This was done immediately to prevent formation of $\mathrm{MgSO}_{4}$ conglomerates. $40 \mathrm{~mL}$ Internal standard solution was added, mixed on a vortex mixer for another $30 \mathrm{~s}$, and extract was centrifuged for approximately $5 \mathrm{~min}$ at $5000 \mathrm{rpm}$. $1 \mathrm{~mL}$ aliquot of upper MeCN layer was transfered into $1.5 \mathrm{~mL}$ microcentrifuge test tube containing $25 \mathrm{mg}$ PSA sorbent and $150 \mathrm{mg}$ anhydrous $\mathrm{MgSO}_{4}$ and capped. The mixture was then shaken with Vortex mixer for $30 \mathrm{~s}$. Extracts were centrifuged for $1 \mathrm{~min}$ at $6000 \mathrm{rpm}$ to separate solids from solution, and $0.5 \mathrm{~mL}$ of extract was transferred to HPLC analysis.

High performance liquid chromatography machine Waters 600 Controller model was used for analysis. The machine was connected to a detector Waters 484 Tunable Absorbance Detector model. Acetonitrile and water were used as mobile phase in a ratio of 80:20 v/v respectively. The column (LiChrospher® $100 \mathrm{Rp}-18,5 \mu \mathrm{m}$ ) was at room temperature while the flow rate was $1 \mathrm{ml} / \mathrm{min}$. The wavelength of the detector was set at $205 \mathrm{~nm}$ with a sensitivity of $0.5 .20 \mu \mathrm{L}$ of extract was injected into the HPLC machine for analysis using a micro-syringe.

\section{RESULTS}

\section{Recovery Assays}

Fresh vegetable samples (Collard greens, tomatoes and swiss chard) were gotten from a home vegetable garden that has never been sprayed with pesticides. They were used in testing the recovery rates of the pesticides using the QuEChERS method. The samples were first analysed to ascertain that they really had no pesticide residues since the farmers do not use chemical pesticides. The vegetables were spiked with known concentration of pesticide standards. Extraction of pesticide was done using the procedure and analysed to determine the recovery rate. This was done in triplicates for the three types of vegetables. The results of the recovery percentages from the vegetables were as indicated in Table 1.

Table 1: Mean Recovery rates of pesticides

\begin{tabular}{|lll|}
\hline Vegetables & Cypermethrin (\% Mean \pm SD) & Lambda-Cyhalothrin $(\%$ Mean \pm SD) \\
\hline Collard greens & $95.7 \pm 0.01$ & $91.97 \pm 0.019$ \\
Tomatoes & $87.78 \pm 0.014$ & $90.65 \pm 0.049$ \\
Swiss chard & $97.93 \pm 0.006$ & $95.72 \pm 0.023$ \\
\hline
\end{tabular}

Concentration of lambda-cyhalothrin and Cypermethrin in vegetables 
Table 2: Concentration of Cypermethrin and Lambda-Cyhalothrin residues

\begin{tabular}{|c|c|c|c|c|}
\hline Markets & Vegetables & & $\begin{array}{l}\text { Cypermethrin } \\
(\text { Mean } \pm \text { SD)mg/kg }\end{array}$ & $\begin{array}{l}\text { Lambda-cyhalothrin } \\
(\text { Mean } \pm \text { SD)mg/kg }\end{array}$ \\
\hline Soko-mjinga & Collard & greens & $1.397 \pm 0.478$ & $0.262 \pm 0.108$ \\
\hline Ponda-mali & Collard & greens & $0.982 \pm 0.265$ & $0.341 \pm 0.164$ \\
\hline Main Municipal Market & Collard & greens & $0.238 \pm 0.132$ & $0.219 \pm 0.427$ \\
\hline Kalimoni Greens & Collard greens & & B.D.L & B.D.L \\
\hline Carre & Collard greens & & B.D.L & B.D.L \\
\hline Karen Organics & Collard greens & & B.D.L & B.D.L \\
\hline Soko-mjinga & Swiss chard & & $2.458 \pm 0.298$ & $0.352 \pm 0.193$ \\
\hline Ponda-mali & Swiss & chard & $2.495 \pm 0.109$ & $0.24 \pm 0.045$ \\
\hline Main Municipal Market & Swiss & chard & $1.462 \pm 0.239$ & $0.28 \pm 0.365$ \\
\hline Kalimoni Greens & Swiss chard & & B.D.L & B.D.L \\
\hline Carre & Swiss chard & & B.D.L & B.D.L \\
\hline Karen Organics & Swiss chard & & B.D.L & B.D.L \\
\hline Soko-mjinga & Tomatoes & & $0.232 \pm 0.085$ & $0.081 \pm 0.037$ \\
\hline Ponda-mali & Tomatoes & & $0.296 \pm 0.076$ & $0.046 \pm 0.049$ \\
\hline Main Municipal Market & Tomatoes & & $0.401 \pm 0.052$ & $0.119 \pm 0.052$ \\
\hline Kalimoni Greens & Tomatoes & & B.D.L & B.D.L \\
\hline Carre & Tomatoes & & B.D.L & B.D.L \\
\hline Karen Organics & Tomatoes & & B.D.L & B.D.L \\
\hline
\end{tabular}

Generally, the results indicated that the concentration of pesticide residues in all organically grown vegetable samples were below detectable levels while conventional vegetable samples had pesticide residues as shown in table 2. It was also noted that swiss chard had the highest concentration of pesticide residues among all the vegetables. The concentration of pesticide residues in swiss chard ranged between 1.462 and $2.495 \mathrm{mg} / \mathrm{kg}$ for cypermethrin and between 0.352 and $0.24 \mathrm{mg} / \mathrm{kg}$ for lambda-cyhalothrin. On the other hand, tomatoes had the lowest residues of both pesticides which ranged between 0.232 and $0.401 \mathrm{mg} / \mathrm{kg}$ for cypermethrin and between 0.046 and $0.119 \mathrm{mg} / \mathrm{kg}$ for lambda-cyhalothrin.

\section{DISCUSSION}

The concentration of pesticide residues in all organic vegetable samples were below detectable levels. This hence confirms that farmers practicing organic agriculture adhere to the principles of organic agriculture which discourages use of chemical pesticides. Hence organic produce are safer since during analysis, there were no peaks produced to indicate that there were other detectable pesticides.

The concentration of Lambda-cyhalothrin in conventional vegetable samples were lower than Cypermethrin. This is because farmers may be spraying more Cypermethrin oftenly than labdacyhalothrin. The low residue concentration of lambda-cyhalothrin can also be attributed to its 
shorter half-life compared to Cypermethrin. This means that it degrades faster in the vegetables or on the surface than Cypermethrin hence the low concentration in them.

The maximum residue levels for Cypermethrin in collards, swiss chard and tomatoes are $1 \mathrm{mg} / \mathrm{kg}$, $2 \mathrm{mg} / \mathrm{kg}$ and $0.2 \mathrm{mg} / \mathrm{kg}$ respectively (FAO/WHO, 2009). Collard greens from Soko-mjinga $(1.397 \pm 0.478 \mathrm{mg} / \mathrm{kg})$, swiss chard from Soko-mjinga $(2.458 \pm 0.298 \mathrm{mg} / \mathrm{kg})$ and Ponda-mali $(2.495 \pm 0.609 \mathrm{mg} / \mathrm{kg})$ and tomatoes from all the three markets exceeded the recommended level.

The recommended residues levels for Lambda-Cyhalothrin is $0.3 \mathrm{mg} / \mathrm{kg}$ in the vegetables (FAO/WHO, 2009). Collard greens from Ponda-mali $(0.341 \pm 0.164 \mathrm{mg} / \mathrm{kg}$ ) and swiss chard from Soko-mjinga $(0.352 \pm 0.193 \mathrm{mg} / \mathrm{kg})$ exceeded the recommended levels. This shows that consumers are likely to suffer negative chronic health effects due to exposure to the pesticide. Tomatoes from Soko-mjinga and Ponda-mali had the least residue levels of $0.081 \pm 0.037$ and $0.046 \pm 0.049$ respectively.

Exposure to high doses of synthetic Pyrethroids such as Lambda-cyhalothrin and Cypermethrin affect sodium channels of nerve cell axons leading to hyperexcitation (Macan et al., 2006 \& Bradberry et al., 2005). Other health effects include uncoordination, whole-body tremors, chloreoathetosis and seizures (Ray et al., 2000).

In conclusion, organic vegetable samples are safer than conventionally grown vegetables as the concentration of pesticide residues were below detectable levels. Consumers of conventional vegetables are exposed to pesticide residues which can cause negative health effects.

It is recommended that farmers should be encouraged to practice organic agriculture to safeguard their health as well as those of consumers as it reduces exposures to pesticides.

\section{Conflict of Interest Declaration}

Some of the authors are involved in Ecological Organic Agriculture, however, they were not directly involved in sampling or laboratory analysis of the samples.

\section{Acknowledgement}

I wold like to acknowledge Egerton University Alumni Association, Biovision Africa Trust and SSNC.

\section{REFERENCES}

[1] Hossain, M.S., Fakhruddin, A.N.M., Chowdhury, A.Z.M., Rahman, M.A. \&Alam K.M. (2015). Health risk assessment of selected pesticide residues in locally produced vegetables of Bangladesh. International Food Research journal 22(1): 110-115.

[2] FAO\&WHO, (2006). Chapter 8; Updating the Principles and Methods of Risk Assessment: Maximum Residue Levels (MRLs) for pesticides and Veterinary drugs. 
[3] Malhat, F., Loutfy, N.M. \& Ahmed, M.T. (2016). Dissipation pattern and risk assessment of the synthetic pyrethroid lambda-cyhalothrin applied on tomatoes under dryland conditions, a case study. International Journal of Food Contamination, 3(2016):8.

[4] Ata, S., Wattoo, F. H., Feroz, M., Wattoo, M. H. S., Tirmiz, A. S., Wadood, A. \& Gulfraz, M. (2013). Analytical investigation of selected pesticide residues from fruits and vegetables by improved exctraction method using reverse phase high performance liquid chromatography. Pakistan Journal of Biochemistry and Molecular Biology, 46(1):1-4.

[5] Unsworth, J., (2010). History of pesticide use. International Union of Pure and applied chemistry.

[6] Fishel, F. M., (2013). Management and pesticides: A historical perspective. University of Florida.

[7] Corbett J.R.(1974). Mode of action of pesticides. In 'The biochemical mode of action of pesticides'. Academic press, 23-24

[8] Anastassiades M. \& Lehotay S. J. (2003). Fast and Easy Multiresidue Method Employing Acetonitrile Extraction/Partitioning and "Dispersive Solid-Phase Extraction" for the determination of Pesticide residues in Produce. Journal of AOAC International 86(2).

[9] Bradberry S.M., Cage S.A. Proudfoot A.T. \& Vale J.A. (2005). Poisoning due to Pyrethroids. Toxicol Rev. 2005;24(2):93-106.

[10] Macan J., Varnal V.M. \& Turk R. (2006). Health effects of pyrethrins and Pyrethroids. Arh Hig Rada Toksikol. 57(2):237-243.

[11] Ray D.E., Ray D. \& Forshaw P. J. (2000). Pyrethroid Insecticides: Poisoning Syndromes, Synergies and Therapy. Journal of toxicology: Clinical Toxicology. 38(2):95-101. 